\title{
THE RESISTANCE OF CONSERVATIVE ISLAMIC ORGANIZATIONS ON THE DEVELOPMENT OF REGIONAL TOURISM IN MADURA
}

\author{
Abd Hannan \\ Institut Agama Islam Negeri (LAIN) Madura, hannan.taufiqi@gmail.com \\ (c) 1 ( ) \\ (C)2021 by the authors. Submitted for possible open access publication under the terms and conditions \\ of the Creative Commons Attribution-ShareAlike 4.0 International License (CC-BY-SA) \\ license (https://creativecommons.org/licenses/by-sa/4.0/) \\ doi DOI: http://dx.doi.org/10.30983/fuaduna.v5i1.4198

\begin{abstract}
This study examines the resistance behavior of conservative Islamic organizations to regional tourism development in Madura, especially entertainment-based tourism. There are three research questions in this study: how is the reality of conservative Islamic organizations in Madura to the religious dynamics of the local community? How is the existence of conservative Islamic organizations to the dynamics of tourism development in Madura? How is the resistance of conservative Islamic organizations towards tourism development in Madura? Qualitative data were collected through observation, interview, and literatures study. The findings show: First, the conservativism values of Islamic organizations in Madura were born and spread widely from local traditions and religions; Second, the tradition of conservatism of Islamic organizations in Madura seen in several Islamic organizations, mainly right-wing Islamic organizations such as AUMA, FKM, and GUIP; Third, the conservatism of Islamic organizations in Madura is related to their resistant behavior towards tourism development in Madura, which reflect in their thinking and religious paradigms which tend to be traditionalist, puritanical, and reactionary. They use anarchism approaches that lead to violence, for instance burning the Bukit Bintang tourist site in Pamekasan Regency.
\end{abstract}

Keywords: Resistance; Conservative Islamic Organizations; Madura Tourism Development.

\begin{abstract}
Abstrak
Studi ini mengkaji perilaku resisten Ormas Islam konservatif terhadap pembangunan pariwisata daerah di Madura, kbususnya pariwisata berbasis hiburan. Terdapat tiga pertanyaan penelitian pada studi ini: bagaimana realitas Ormas Islam konservatif di Madura dalam dinamika keagamaan masyarakat setempat? Bagaimana eksistensi Ormas Islam konservatif dalam dinamika pembangunan pariwisata di Madura? Bagaimana resistensi Ormas Islam konservatif terhadap pembangunan parivisata di Madura? Kualitatif data dikumpulkan melalui observasi, wawancara, dan studi kepustakaan. Temuan studi ini menunjukan: Pertama, nilai-nilai konservatisme Ormas Islam di Madura lahir dan menyebar luas dari tradisi dan keagamaan lokal; Kedua, tradisi konservatisme Ormas Islam di Madura dapat ditemukan di sejumlah Ormas Islam, terutama Ormas Islam yang secara ideologi berhaluan kanan seperti AUMA, FKM, dan GUIP; Ketiga, konservatisme Ormas Islam di Madura terkait perilaku resisten mereka terhadap pembangunan pariwisata di Madura, tergambarpada paradigma berpikir dan keagamaan mereka yang cenderung tradisionalis, puritan, dan reaksioner. Mereka menggunakan pendekatan anarkisme sehingga berujung pada tindak. kekerasan seperti pada kasus pembakaran lokasi wisata Bukit Bintang di Kabupaten Pamekasan.
\end{abstract}

Kata Kunci: Resistensi; Ormas Islam Konservatif; Pembangunan Pariwisata Madura. 


\section{INTRODUCTION}

As an archipelagic area, Madura is known to have many values local wisdom in many social studies. One of their local wisdom values resides in their society and system building, identical to two values at once, namely religious values and traditional values. ${ }^{1}$ In the aspect of religiosity, the Madurese have considerable respect for religious symbols. In this regard, various local religious symbols, especially those that rely on the charisma and greatness of Kiai, pesantren, and the Islamic organization Nahdatul Ulama (read: NU), all of which have a central position and influence that controls the social activities of the Madurese community in many aspects. ${ }^{2}$ While in the traditional element, the characteristics of Madurese traditionalism can be traced to their religious typology, which is thick with conservative values. That is a classical religious perspective that adheres to the scriptures or the teachings of orthodoxy and tradition.

Concerning the religious conservativeness of the Madurese community, several studies have been conducted on this topic. The latest study comes from Ahmad Najib Burhani (2019), Lessons from Madura: NU, Conservatism and the 2019 Presidential Election. In this paper, Najib Burhani focuses his study on the existence, role, and influence of nahdiyyin community groups and conservative groups in Madura in the dynamics of the 2019 Presidential Election. This study found that although the Islamic tradition of the Madurese community is known as related and loyal to the big-name NU Islamic Organization, the atmosphere tends to be conservative. It can be

1 Martin van Bruinessen, "Tarekat and Tarekat Teachers in Madurese Society". In Across Madura Strait: The Dynamics of an Insular Society, Edited by Kees van Dijk, Huub de Jonge, and Elly Touwen-Bouwsma (Leiden: KITLV Press, 1995).

2 Samsul. Ma'arif, The History of Madura; Sejarah Panjang Madura Dari Kerajaan, Kolonialisme, Sampai Kemerdekaan (Yogyakarta: Araska, 2015).

3 Abd A'la et al., 'Islamism in Madura: From

Religious Symbolism to Authoritarianism', Journal of Indonesian Islam 12, no. 2 (1 December 2018): 159, https://doi.org/10.15642/JIIS.2018.12.2.159-194. seen in the behavior that always adheres to the holy book's teachings, claiming the correct reference. According to him, conservativism is an inseparable part of the identity of the Madurese community. It not only influences the religious aspect but also their behavior in politics.

Another study that examines the phenomenon of religious conservatism in Madura comes from Abd A'la, et al. (2018), Islamism in Madura: From Religious Symbolism to Authoritarianism. In this study, A'la sees the socio-religious construction of the Madurese community as a religious group dominated by two major groups, namely the NU group as the majority group, and the other one is the Sarekat Islam (SI) group. ${ }^{3}$ However, outside the two central poles of Islamic Organizations, many other religious organizations are no less powerful and influential, including the Madura Ulama Alliance (AUMA) and the Madura Young Kiai Forum (FKM). ${ }^{4}$ Based on the findings of his study, A'la said that AUMA and FKM are the most explicit pictures to portray the conservativism of Islamic organizations in Madura. In general, both conservatives can be seen from their religious patterns and behavior, which tend to be normative, exclusive, and reactionary in responding to various current social issues. There are several social issues that come into contact with religious themes and other issues outside of it. One of them is the issue of regional development politics in Madura. ${ }^{5}$

Concerning the existence and role of conservative Islamic organizations in Madura's discourse, the relationship between the two can be seen in many ways. For example, in terms of

4 Abd A'la, Ahwan Mukarrom, and Mukhammad Zamzami, 'Kontribusi Aliansi Ulama Madura (AUMA) dalam Merespons Isu Keislaman dan Keumatan di Pamekasan Madura', Religió: Jurnal Studi A\& a-a\& a 8, no. 2 (8 September 2018): 227-55, https://doi.org/10.15642/religio.v8i2.793.

5 Abd A'la, Ahwan Mukarrom, and Mukhammad Zamzami, 'Kontribusi Aliansi Ulama Madura (AUMA) dalam Merespons Isu Keislaman dan Keumatan di Pamekasan Madura', Religió: Jurnal Studi A\& a-a\& a 8, no. 2 (8 September 2018): 227-55, https://doi.org/10.15642/religio.v8i2.793. 
economic development, the role and influence of conservative Islamic groups are clearly illustrated by their involvement in several local government policies. It can be seen when they are in charge of policies or development agendas that they think are contrary to religious values often lead the critics. ${ }^{6}$ In some cases, they did not hesitate to take intimidating and repressive actions for instance forced closure of entertainment venues such as Karaoke Wira Raja, rejection of the KCM Cinema in Pamekasan. The most shocking thing was their refusal to develop tourism in the Bukit Bintang area in Pamekasan Regency, which resulted in destruction and burning. ${ }^{7}$

Based on the above framework, this study aims to conduct an in-depth analysis of the resistance of conservative Islamic organizations in Madura to tourism development in Madura, especially in entertainment. Methodologically, this study uses a type of qualitative research. The selection of this research is based on the research objective: to present an in-depth and comprehensive analysis of the dynamics of conservative Islamic groups in Madura, their existence, and their role in the dynamics of tourism development in Madura. While theoretically, this study will focus its examination on the sociology of religion and the sociology of development. From a sociological perspective, this research takes a focused position by conducting studies on sociological aspects, including social behavior and actions related to the resistance of conservative Islamic groups to tourism development in Madura. In general, the value of urgency and interesting

6 Yanwar Pribadi, 'Religious Networks in Madura: Pesantren, Nahdlatul Ulama, and Kiai as the Core of Santri Culture', Al-Jami'ah: Journal of Islamic Studies 51, no. 1 (15 June 2013): 1, https://doi.org/10.14421/ajis.2013.511.1-32.

7 C. N. N. Indonesia, 'Diiringi Takbir, Massa Bakar Kedai Bukit Bintang di Pamekasan', https://www.cnnindonesia.com, 10 May 2020, https://www.cnnindonesia.com/nasional/20201005132718 -20-554475/diiringi-takbir-massa-bakar-kedai-bukitbintang-di-pamekasan.

8 Abdurrahman, Sejarah Madura Selayang Pandang (Sumenep: Matahari, 1988). side of this study lie in the primary research issues that have not been raised and answered by previous studies, both library-based and field research. The main research issue referred to the dynamics of Islamic organizations in Madura and their resistance to tourism development in Madura.

\section{THE STATISTIC OF TOURISM DEVELOPMENT IN MADURA}

Geographically, Madura is an archipelago located just north of the city of Surabaya with coordinates around seven degrees south latitude and between 112 and 114 degrees east longitude. Administratively, Madura Island is inhabited by four regencies, namely Bangkalan, Sampang, Pamekasan, and the last is Sumenep Regency. ${ }^{8}$ Like the archipelago in general, Madura Island has many small islands widely spread in many directions, especially in the east of Sumenep district. Based on the latest data, there are no less than 127 small islands, of which 48 are inhabited, and the rest are not. Interestingly, several islands such as Gili Yang Island and Gili Labak Island are both listed as rare islands because they have the best oxygen levels in the world.'

The dynamics of tourism development in Madura is far from fair to be admitted as a core strength to develop the economy. ${ }^{10}$ So far, of the overall tourism potential in Madura, both based on natural resources and socio-cultural, efforts to strengthen the tourism industry are only in a few sectors, even using the general method by still

${ }^{9}$ Hairil Hiar, 'Top 3: Pulau Berkadar Oksigen Terbaik Dunia Ada di Madura', liputan6.com, 19 July 2016, https://www.liputan6.com/regional/read/2556406/top-3pulau-berkadar-oksigen-terbaik-dunia-ada-di-madura; kumparan, 'Pulau di Sumenep Ini Punya Oksigen Terbaik ke2 di Dunia', kumparan, accessed 30 January 2021, https://kumparan.com/kumparantravel/pulau-disumenep-ini-punya-oksigen-terbaik-ke-2-di-dunia1rYusRzdcJK.

10 JawaPos.com, 'Pengelolaan Wisata Belum Maksimal', 23 January 2018, https://radarmadura.jawapos.com/read/2018/01/23/4257 5/pengelolaan-wisata-belum-maksimal. 
relying on spots or the same places. ${ }^{11}$ In Pamekasan Regency, for example, based on data collected from the local statistical center agency, of the many existing tourism potentials, only six tourist sites have been driven. Ironically, most of them centered on classical religious tourism, nature conservation tourism, and cultural tourism. So that the impact on the lack of interest of tourists who visit to enjoy tourist attractions in Madura, both local tourists, especially foreign tourists (see Table 1). ${ }^{12}$

Tabel 1. Number of Tourist Destination Visitors by Destionation and the tourist origin-2019

\begin{tabular}{lcc}
\hline Tourist & \multicolumn{2}{c}{ 2019 } \\
\cline { 2 - 3 } Destination & Local & Foreign \\
\hline Api Alam & 16.186 & 27 \\
\hline Pantai Jumiang & 48.651 & 23 \\
\hline Talang Siring & 37.367 & 24 \\
\hline $\begin{array}{l}\text { Pasarean Batu } \\
\text { Ampar }\end{array}$ & 52.115 & 11 \\
\hline $\begin{array}{l}\text { Makam Ronggo } \\
\text { Sungkowati }\end{array}$ & 1.147 & 13 \\
\hline $\begin{array}{l}\text { Musem } \\
\text { Mandhilaras }\end{array}$ & 2619 & 10 \\
\hline Total & $\mathbf{1 5 8 0 8 4}$ & $\mathbf{1 0 8}$ \\
\hline Source: Pamekan Stam & & \\
\hline
\end{tabular}

Source: Pamekasan dalam Angka 2020, Badan Pusat Statistik. Daerah Pamekasan

Thus, reflecting on the dynamics and problems above, there are at least two factors that cause tourism development in Madura not to run optimally: first, structural elements. This factor is more of a political policy issue that has not fully sided with the tourism development and development plan in Madura. ${ }^{13}$ Both policy politics in the budget sector and the development road

11 Alfisah Nurhayati, 'Revisiting Pariwisata Madura; Studi Kebijakan Pembangunan Kepariwistaan Kabupaten Sampang', KARSA 18, no. 2 (2010): 11.

12 BPS Pamekasan, 'Badan Pusat Statistik Kabupaten Pamekasan', https://pamekasankab.bps.go.id/, accessed 29 January 2021, https://pamekasankab.bps.go.id/.

13 Muchammad Nurif and Endang Sulastri, 'Analisis Perubahan Eksternal dalam Pengembangan Kawasan Wisata Bahari Kepulauan Sapeken Madura dengan Menggunakan Pendekatan Pemasaran Wilayah', Jurnal Sosial Humaniora 10, no. 2 (n.d.): 13. map are not concerned about making tourism a priority scale for regional development strategic designs. Second, the religious-cultural factor, namely this factor, contains the problem of tourism development in Madura, caused by elements of the culture and religious traditions of the surrounding community. In this regard, the culture of the Madurese community, which is religiously identical with conservatism, has to some extent interfered with the development of tourism in Madura. ${ }^{14}$ Included in this religious, cultural problem, expressly the rejection and burning of Bukit Bintang tourism in Pamekasan, the forced closure of the Kapal Hotel, and entertainment venues in the form of Wiraraja karaoke in Pamekasan. The three trigger reactions and resistance from the local community, especially from conservative Islamic mass organizations, because they are considered contrary to the values of Pamekasan local wisdom as the Kota Gerbang Salam. ${ }^{15}$

\section{CONSERVATIVE ISLAMIC ORGANIZATIONS IN MADURA: A DESCRIPTIVE EXPLANATION}

Terminologically, conservatism means a political ideology that wants to maintain tradition and social stability, preserve long-standing institutions, requires development step by step, and challenges radical change. ${ }^{16}$ That means conservatism means an understanding that involves establishing the past social system buildings that have emerged since earlier times. ${ }^{17}$

14 Fithriyah Rahmawati, 'Strategi Pembangunan Pariwisata Daerah Berkelanjutan Melalui Konsep Ekowisata Berbasis Kearifan Lokal' 2, no. 1 (June 2020): 24.

15 Abd Hannan, 'Problem Tafsir Gerbang Salam', Kabar Madura, 10 March 2020, https://kabarmadura.id/problem-tafsir-gerbang-salam/.

${ }^{16}$ Departemen Pendidikan dan kebudayaan, Kamus Besar Bahasa Indonesia (Edisi Kedua) (Jakarta: Balai Pustaka, 1999).

17 Amin Mudzakkir, 'Konservatisme Islam dan Intoleransi Keagamaan di Tasikmalaya', Harmoni 16, no. 1 (30 June 2017): 57-74, https://doi.org/10.32488/harmoni.v16i1.56; Irvan Tasnur, 
As for etymologically, some literature defines religious conservatism as the desire to maintain the 'pure' doctrines that were originated and practiced by the bearers of the teachings of hundreds of years ago. While it is popularly known as 'religious conservatism in the academic world, Azumardi Azra defines a paradigm of religious thinking and behavior that always adheres to the holy book's teachings, which they claim as the correct reference. ${ }^{18}$

In subsequent developments, conservatism underwent an involution process into neoconservatism. ${ }^{19}$ However, despite experiencing the commodification of terminology, all parties agree that conservatism and nonconservatism require the same object and understanding. They both need strength in religion, both in thinking and acting. Tend to be textual, ahistorical, and resistant to contemporary religious issues that have a modernist matter. This group believes that there is no other way and way of obtaining true peace and comfort except by returning to the teachings and practices of previous religions and avoiding all forms of reform efforts as currently being campaigned by modernists. ${ }^{20}$ As a religious ideology, conservatism groups exist in every world religion, such as Islam, Christianity, Buddhism, etc. In addition, its existence is also widespread in many corners of the

'Akar dan Perkembangan Konservatisme Islam dalam Perpolitikan Indonesia', Jurnal review Politik 09, no. 1 (2019): 22.

18 Azyumardi Azra, 'Konservatisme Agama', Republika Online, 1 August 2019, https://republika.co.id/berita/pvistt282/konservatismeagama-1.

19 Abd Hannan, 'Moderatisme dan Problem Konservatisme Beragama di Tengah Pandemi Global Covid19', Jurnal KURIOSITAS; Media Komunikasi Sosial dan Kea\& aan 13, no. 2 (Desember 2020): 31; Din Wahid, 'Kembalinya Konservatisme Islam Indonesia', Studia Islamika 21, no. 2 (12 November 2014), https:/ / doi.org/10.15408/sdi.v21i2.1043.

20 Fachri Aidulsyah and Yuji Mizuno, 'The Entanglement Between Anti-Liberalism And Conservatism: The INSISTS and MIUMI Effect within the "212 Movement" in Indonesia', JOURNAL OF INDONESLAN ISLAM 14, no. 1 (1 June 2020): 1, https://doi.org/10.15642/JIIS.2020.14.1.1-25. world, especially countries or regions that have normative and traditional religious cultures. ${ }^{21}$

Concerning conservative Islamic organizations in Madura, as mentioned earlier, Madura has a solid local wisdom value with religious values. This religiosity is reflected in the attitudes and behavior of those who have considerable respect for religious symbols. ${ }^{22}$ That religious symbols such as the Kiai's character, the popularity of pesantren, and the big names of religious organizations are all three classified as inseparable elements of the life of the Madurese community. ${ }^{23}$ Using what Noer Cholis Madjid (1992) terms, the existence of Kiai, pesantren, and Islamic organizations is an integral reality that reflects the identity of the Madurese community. But more than that is a manifestation of the existence of regional authenticity that has merged with their social life activities in all aspects. Both in terms of economy, education, culture, especially in terms of religion. ${ }^{24}$

Like most regions in Indonesia in general, the reality of Islam in Madura is quite heterogeneous. This heterogeneity can be found in the many Islamic understandings and organizations that the local community has embraced..$^{25}$ At the level of knowledge or sect, in Madura, there are sects of Sunni Islam and Shia Islam, two different sects which in their history have often been involved in prolonged conflicts.

${ }^{21}$ Dan Asia, 'A Conservatism That Makes No Sense', Academic Questions 33, no. 2 (1 October 2020): 1-5, https://doi.org/10.1007/s12129-020-09920-8.

22 Bruinessen, "Tarekat and Tarekat Teachers in Madurese Society". In Across Madura Strait: The Dynamics of an Insular Society, Edited by Kees van Dijk, Huub de Jonge, and Elly Touwen-Bouwsma.

23 Ma'arif, The History of Madura; Sejarah Panjang Madura Dari Kerajaan, Kolonialisme, Sampai Kemerdekaan.

${ }^{24}$ Nurcholis Madjid, Bilik-Bilik Pesantren Sebuah Potret Perjalanan (Jakarta: Paramadina, 1992).

25 Abd Hannan, Islam Moderat dan Tradisi Popular Pesantren: Strategi Penguatan Islam Moderat di Kalangan Masyarakat Madura melalui Nilai Tradisi Popular Islam Berbasis Pesantren', Jurnal Sosiologi Dialektika 13, no. 2 (16 May 2020): 152, https://doi.org/10.20473/jsd.v13i2.2018.152-168. 
Meanwhile, at the CSOs level, the heterogeneity of Islam in Madura is reflected in religious organizations. Several religious organizations such as NU, Muhammadiyah, Sarekat Islam, Persis, HTI, FPI, are all forms of religious organizations taking place in Islamic discourse in Madura. ${ }^{26}$ In addition to the above organizations, there are also local Islamic organizations established by pesantren circles, especially kiai and lora. Some of them that are quite active are GIUP, GESPER, BASSRA, AUMA, FKM. ${ }^{27}$ The last two names are listed as "extreme right" Islamic organizations that are actively involved in responding to contemporary religious issues, particularly to several local government policies that they consider not in line with the Islamic vision in Madura.

The interesting thing about the existence of Islamic organizations in Madura is their religious traditions. Even though Islam in Madura is divided into several groups or mass organizations, they have similarities in religious practices. In general, the side of the equation is in their Islamic character and practices, which tend to emphasize conservatism, both in thinking and acting. ${ }^{28}$ Even the NU Islamic Organizations, which have been known to be relatively moderate, in Madura they also tend to be conservative. Especially the cultural NU circles, whose existence is widespread in many salaf-based Islamic boarding schools. ${ }^{29}$ Apart from that, the most dominant conservatism of Islamic organizations in Madura can actually be found in the existence of right-wing Islamic organizations. The right term here refers to

${ }^{26}$ Zainuddin Syarif and Abd Hannan, 'Kearifan Lokal Pesantren Sebagai Bangunan Ideal Moderasi Islam Masyarakat Madura', ISLAMICA: Jurnal Studi Keislaman 14, no. 2 (1 March 2020): 220-40, https://doi.org/10.15642/islamica.2020.14.2.220-240.

27 Abd A`la, Ahwan Mukarrom, and Mukhammad Zamzami, 'Islam Dan Agamaisasi Politik: Studi Analisis Terhadap Peran Dan Pergerakan Forum Kiai Muda (FKM) Pamekasan Madura', Jurnal Review Politik 8, no. 1 (22 February 2019), http://jurnalfuf.uinsby.ac.id/index.php/JRP/article/view/ 1089; A'la, Mukarrom, and Zamzami, 'Kontribusi Aliansi Ulama Madura (AUMA) dalam Merespons Isu Keislaman dan Keumatan di Pamekasan Madura', 8 September 2018. their Islamic culture, emphasizing normative, textual, literal, reactionary, and exclusivist values. Included in this category are AUMA Islamic Organizations, FKM, and finally GUIP. Further explanation of these three CSOs (Civil Society Organization) will be fully explained in the following sub-chapters.

a) Aliansi Ulama Madura (AUMA)

Aliansi Ulama Madura (AUMA) is a relatively new Islamic organization. This organization was founded at the Nurul Kholil Islamic Boarding School, Bangkalan Regency, precisely on October 31, 2015. As an association of Madurese scholars, the management of AUMA has been formed since July 21, 2015 in Pamekasan Madura, precisely at the Darul Ulum Islamic Boarding School Banyuanyar. Currently, AUMA has its head office in Pamekasan, precisely in Lenteng Village, Proppo District, Pamekasan Regency. Structurally, AUMA is led by Kiai Ali Karrar Shinhaji, who is also the leader of the Darut Tauhid Islamic Boarding School Misdat Pamekasan. ${ }^{30}$

Based on its religious understanding, AUMA adheres to the teachings of sunnah wal Jama'ah experts who stick firmly to the holy book and the teachings of Islamic orthodoxy, in this case, the Qur'an, hadith, and ijtihad products of previous scholars who adhered to the Manhaj As Salafusholih. As for its vision and mission, AUMA focuses its movement on da'wah activities. It is reflected in their primary agenda, eliminating all forms of religious deviation among the Madurese

28 Muhammad Endy Saputro, Muslim Localizing Democracy:A Non-Pesantren Village in Madura as a Preliminary Study', Indonesian Journal of Islam and Muslim Societies 1, no. 2 (1 December 2011): 297, https://doi.org/10.18326/ijims.v1i2.297-316; Afif Amrullah, 'Islam Di Madura', Islamuna: Jurnal Studi Islam 2, no. 1 (5 June 2015): 56, https://doi.org/10.19105/islamuna.v2i1.654.

29 Lihat Ahmad Najib Burhani, Less ons from Madura: NU, Conservatism and the 2019 Presidential Election', no. 2019 (2019): 9.

${ }^{30}$ KH.H Abdullah, Interview Bersama Ulama/Kyai Pesantren, 3 June 2020. 
community, both deviations in the form of sects and religious practices. Several religious notions such as Shia, Wahhabis, Liberals, and all forms of harassment and blasphemy against religion, four are contemporary religious issues that they are strongly challenging. Because of this vision, AUMA often appears to the public, actively responding to various socio-religious contemporary problems. Even on many occasions, AUMA does not hesitate to express criticism and rejection of all forms of government policies that are not in line with the truth values they profess. Including the procedure of building some entertainment and tourism places in Madura which, according to them, is contrary to Islamic values.

Concerning the dynamics of tourism development in Madura, AUMA is the most vocal and active religious organization showing resistance to tourism development in Madura. Based on field data, we can find AUMA's resistant behavior in their refusal to build several family entertainment and tourism places in Pamekasan, including the construction of the KCM Mall Cinema Building (2019), ${ }^{31}$ three-star hotel in the shape of a cruise ship in Tlanakan Pamekasan (2011), forced closure of karaoke entertainment at Wiraraja Tlanakan Pamekasan (2018), and most recently their rejection of Bukit Bintang tourism development in Palengaan Pamekasan (2020). ${ }^{32}$

\section{b) Forum Kiai Muda Madura (FKM)}

Like AUMA, the Islamic Organization for Kiai Muda Madura (FKM) is also a relatively new religious organization in Madura. FKM was officially established on August 9th, 2015, at the Misdat Islamic Boarding School in Lenteng Village, Proppo District, Pamekasan Regency. It is

31 Redpel, 'Penutupan Cafe Wiraraja Terkesan Aksi Simbolis Satpol PP', JATIM POS online, 23 June 202AD, https://www.jatimpos.co/jatim/pantura/2423-penutupancafe-wiraraja-terkesan-aksi-simbolis-satpol-pp; Indonesia, 'Diiringi Takbir, Massa Bakar Kedai Bukit Bintang di Pamekasan'.

32 Tempo.co, 'Disegel Kiai, Hotel Terbesar Di Madura Dijual -', Nasional Tempo.co, Mei 2011, https:// nasional.tempo.co/read/333261/disegel-kiai-hotel- a place for the association of young Madurese ulama and religious leaders (Javanese: Gus). The FKM management composition mostly leads by the youth and religious teachers of Islamic boarding schools between the ages of 20-40 years. The organization based in Pamekasan is led by Lora Umar Hamdan Karrar, son of KH Ali Karrar Shinhaji, the leader of the Madura Ulama Alliance (AUMA) organization who is also the caretaker of the Darut Tauhid Islamic Boarding School Misdat Pamekasan. A large conservative Islamic boarding school in Madura. The secretary of FKM is Lora Imadul Haq Fadholi, son of KH Fadholi Moh. Ruham, caretaker of the al-Fudhola Islamic Boarding School in Pamekasan Regency who is also the secretary-general of AUMA. ${ }^{33}$

In terms of religion, FKM adheres to the same religious understanding as AUMA, namely the abli sunnah wal jamaab by firmly adhering to the primary sources of Islam, namely the holy book and the teachings of Islamic orthodoxy. The various thoughts and religious rituals that exist in AUMA are also found in FKM. If AUMA is the parent, then FKM is a subsidiary of AUMA. That is why, in many ways FKM has similarities with AUMA, including regarding its vision and mission. Namely carrying out the purification of Islam among the Madurese Muslim community, especially the vision of saving from various Islamic religious practices and teachings that contain Shi'a sect, Wahabi, and Liberalism understandings. Based on field data searches, FKM's biggest contribution to preaching was when they held a tabligh akbar event in Pamekasan (13 April 2017), which at that time was attended by the Grand Imam of the Islamic Defenders Front (FPI), Muhammad Rizieq Shihab. ${ }^{34}$

terbesar-di-madura-dijual; Made Asdhiana, 'Ulama Madura Segel Hotel Berbintang', https://ekonomi.kompas.com/, 27 April

2011,

https://ekonomi.kompas.com/read/2011/04/27/1914585

3/ulama.madura.segel.hotel.berbintang.

${ }^{33}$ KH. Umar Hamdan Karrar, Wawancara Bersama

Ketua Forum Kyai Muda Madura, 30 July 2018.

34 MATAMADURANEWS.COM, 'Hadiri Tabligh

Akbar Di Pamekasan, Habib Rizieq Serukan Partai 
Regarding the dynamics of tourism and entertainment development in Madura, in general, the resistance of FKM is reflected in their attitude, which is often oppositional, criticizing, and even challenging several local government policies regarding the strengthening of the tourism industry in Madura. For example, their rejection of entertainment programs in the form of Irwan's dangdut concert in Pamekasan, the construction of the KCM Mall Cinema Building, the existence of hotels and entertainment venues in Madura that provide karaoke services. ${ }^{35}$ Recently, many FKM members took part in the rejection of the Bukit Bintang tourist spot in Palengaan Pamekasan. Joined with other mass organizations such as FPI and AUMA, they held actions with hundreds of masses, carried out forced closures, and burned related tourist attractions.

In addition to the two Islamic organizations above, many other mass organizations in Madura are quite active in rejecting several tourism developments and family entertainment places in Madura. Two of the conservative Islamic organizations that are no less vocal than AUMA and FKM are the Islamic CSOs GUIP and the Islamic CSOs FPI. GUIP, who choose to resist the development of tourism and entertainment locations in Madura, can be traced by their rejection of a cinema in Pamekasan. Joined with AUMA, FKM, GUIP took joint action, demanding the local government not to build entertainment facilities that could become a gathering place for young people because they were considered to have great potential for

Pendukung Penista Agama Tak Boleh Didukung Ulama Mata Madura', https://matamaduranews.com/, 13 April 2017, https://matamaduranews.com/hadiri-tabligh-akbardi-pamekasan-habib-rizieq-serukan-partai-pendukungpenista-agama-tak-boleh-didukung-ulama/.

35 ANTARA News Agency, 'Kiai Muda Datangi Bupati Pamekasan Tolak Konser Irwan', ANTARA News Jawa Timur, 21 April 2016, https://jatim.antaranews.com/berita/176401/kiai-mudadatangi-bupati-pamekasan-tolak-konser-irwan; maduranewsmedia, 'AUMA Dan FKM Tolak Konser Irwan di Pamekasan’, MADURA Newsmedia (blog), 20 April 2016, https://maduranewsmedia.com/terkini/auma-dan-fkmtolak-konser-irwan-di-pamekasan/. immorality. As for FPI, as a religious organization with a strong commitment to defending the strengthening of Islam and its teachings, FPI pays considerable attention to the development agenda in Pamekasan, including in the tourism sector. In some cases, they often show a resistance attitude that leads to intimidating-persuasive actions against several government policies, which they feel are contrary to regional Islamic values and become a source of evil. Including actions against family entertainment venues, the Kota Cinema Mall (KCM) cinema building located in Pamekasan. ${ }^{36}$

\section{RESISTANCE PATTERN: SWEEPING, ENFORCEMENT TO CLOSE REGIONAL TOURISM AND BURNING ACTION}

In many social studies, the Madurese are very close to religious values, both culturally and structurally. In the cultural aspect, the religious dimension of the Madurese community is clearly illustrated in their culture and traditions, which have considerable respect for religion and its symbolism, especially among Kiai and the pesantren community in general. ${ }^{37}$ Meanwhile, in the structural aspect, the influence of religion is clearly illustrated in the reality of regional development, which has strong attention to religious dimensions such as norms, politeness, and values. Even in several districts in Madura, religion is used as a unique jargon that functions as a road map for regional development and

36 Pebriansyah Ariefana, 'Ribuan Anggota FPI Turun ke Jalan Demo Mal: Bioskop Sumber Kemaksiatan', suara.com, 15 February 2020, https://jatim.suara.com/read/2020/02/15/060000/ribuan -anggota-fpi-turun-ke-jalan-demo-mal-bioskop-sumberkemaksiatan; 'Sumber Maksiat! Massa FPI Demo Tutup Bioskop di Pamekasan', Solopos.com, 16 February 2020, https://m.solopos.com/sumber-maksiat-massa-fpi-demotutup-bioskop-di-pamekasan-1047150.

${ }^{37}$ Yanwar Pribadi, 'The Suramadu Bridge Affair: UnBridging the State and the Kiai in New Order Madura', Studia Islamika 22, no. 2 (2 September 2015), https://doi.org/10.15408/sdi.v22i2.1919. 
development. ${ }^{38}$ In Pamekasan, for example, the jargon of Gerbang Salam appears, which is an acronym or abbreviation of the Islamic Community Development Movement. ${ }^{39}$ Then in Bangkalan, the district at the western end of Madura has Dhikr and Sholawat City jargon. There is also Sampang Regency with its jargon, City of Santri. ${ }^{40}$ Philosophically, the three regional jargons above contain sociological meanings that describe the reality and local wisdom of the local area as a society that upholds religious values. So that way, every development agenda or process in Madura must contain and support the realization of these values. ${ }^{41}$

This view has been used by the majority of Islamic organizations in Madura. In terms of tourism development in Madura, everything must conform to regional jargon and not contradict the culture of the Madurese community, which is attached to the symbol of religiosity. According to them, the development to create socio-economic welfare for the community must also contain a religious vision, strengthen the moral and moral order, and be sterile from all forms of disobedience, evil, and religious deviations that can threaten the faith of the people. In their view, the religious dimension is the soul or spirit of every development, be it development in the educational, social, or economic fields. When development in the regions is not in line with religious principles, they will firmly reject it. Regarding this, one of the informants said:

"Actually we want to have a dialogue. Before taking action, we have tried to

38 Hannan, 'Islam moderat dan tradisi popular pesantren'.

39 Nasrullah Ainul Yaqin, 'Adakah Pengaruh Penerapan Syariat Islam di Pamekasan Terhadap Lingkungan?: Studi Kasus Kerusakan Laut di Desa Batukerbuy', Al-Irfan: Journal of Arabic Literature and Islamic Studies 1, no. 1 (8 October 2018): 141-81, https://doi.org/10.36835/al-irfan.v1i1.3225.

40 Erie Hariyanto, 'Gerbang Salam: Telaah Atas Pelaksanaanya Di Kabupaten Pamekasan', Karsa: The Journal of Social and Islamic Culture 15 (1 March 2012), https://doi.org/10.19105/karsa.v15i1.116. convey this to the Regent. But the Regent only made promises. We are not antitourism. We also want people to be prosperous, their economy fulfilled. But with a note not to cause harm to safety. For example, by giving a boundary between men and women, and the hours are considered. It's simple, make a regulation like that. When it's time for prayer, everything must be sterilized. If so, of course, we will support it. But if not, then we will certainly reject it because this concerns the creed of the ummah." ${ }^{42}$

About the tourism industry in Madura, according to him, they are not anti-tourism development and crowd activity. However, as is the case with regional jargon and community religiosity culture, tourism industry activities in Madura must support the strengthening of this culture. To go in that direction is not difficult. It is enough to make policies or regulations regarding technical operations, for example, by limiting its operating hours by paying attention to the hours of obligatory prayers. Implement a zoning system based on gender, namely placing men and women in different places. Implement policies so that every tourist or visitor obeys the rules and does not do things contrary to norms, social norms, and religious norms. If all the points above are applied, they will support the development of tourism in Madura. But if not, then, on the contrary, they will firmly challenge and refuse. So, both written refusals in the form of warnings and appeals, to forced rejections as happened in the case of the closure of the Cruise Ship Hotel, Wiraraja cafe and

${ }^{41}$ Abd - Hannan, 'Agama, Kekerasan, dan Kontestasi Politik Elektoral: Penggunaan Simbol Keagamaan Kiai dan Kekuasaan Blater dalam Pertarungan Politik Lokal Madura', Jurnal Sosiologi Agama 12, no. 2 (18 December 2018): 187, https://doi.org/10.14421/jsa.2018.122-02; Abd Hannan and Zainuddin Syarif, 'Agama Dan Politik: Konstelasi Pemikiran Antara Kelompok Kultural Dan Struktural Pada Kalangan Kiai Pesantren Di Madura', Mawa'iz̧: Jurnal Dakwah Dan Pengembangan Sosial Kemanusiaan 11, no. 1 (4 June 2020): 47-73, https://doi.org/10.32923/maw.v11i1.1174.

42 RKH. Ali, Interview Bersama Kyai Pesantren, Pandangan Kyai Pesantren terhadap Pembangunan Pariwisata di Madura, 24 January 2021. 
restaurant, and burning the Bukit Bintang tourist site in Palengaan.

Gambar 1. Conservative Islamic organizations loyalist burn Bukit Bintang Tourism in Pamekasan Regency, Madura

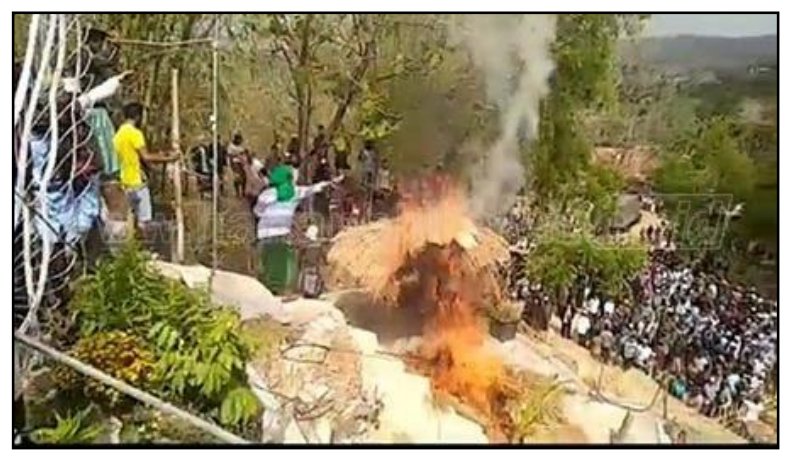

Based on the results of field data collection, from several cases of refusal and forced closure of entertainment and tourism places in Madura, various responses emerged from the local community, some were supportive, and some were not. ${ }^{43}$ Those who agree are arguably the majority group, generally coming from the pesantren community such as Kiai, santri, and grassroots sympathizers. According to them, control and normalization of entertainment and tourism places in Madura need to be done to keep Madura in its religious culture and traditions. Moreover, in Madura, hundreds of Islamic boarding schools and prominent ulama figures are widely spread in many areas, both in Bangkalan, Sampang, and Sumenep, especially Pamekasan. However, outside of this majority group, some people oppose, in the sense that they disapprove of the rejection action that is followed by forced closures, especially if it leads to anarchic activities such as arson and the like. For them, the act of refusal followed by anarchism is an exaggeration. Moreover, it is carried out by religious mass organizations, which should respond subtly to community problems and

43 Prima Gumilang, 'Sweeping Laskar FPI dan Perlawanan Balik Warga Pamekasan', https://www.cnnindonesia.com/, 22 January 2018, https://www.cnnindonesia.com/nasional/20180122065509 -20-270593/sweeping-laskar-fpi-dan-perlawanan-balikwarga-pamekasan.

44 Atika, Respon Masyarakat terhadap Pembakaran Pariwisata Bukit Bintang di Pamekasan, 23 January 2021. prioritize the principle of dialogue. The use of violent methods in solving problems in the community will cause material losses for the surrounding community. In addition, it will also worsen the image of Madura because it is considered not friendly enough to economic development, especially in the tourism sector. ${ }^{44}$

\section{RESISTANCE PATTERN: FROM MASS MOBILIZATION, BUREAUCRATIC, TO POLITICAL ACTION}

Interestingly, in the many actions, Islamic CSOs groups are not alone in carrying it out. They carry out collective movements with other mass organizations, taking advantage of their social networks and power. It means, networks at the community level and power at the bureaucratic level and also the political sector. ${ }^{45}$ At the community level, Islamic Organizations collaborate with several other mass organizations that ideologically share the same vision. Generally, these CSOs are fostered organizations that culturally have strong emotional ties. Included in it are student and alumni union organizations. Almost all pesantren in Madura have their student and alumni associations. Their presence is widespread in many areas, from the central, regional, to rural branches. In Madura, CSOs is not only known to be significant with a strong spirit of brotherhood and unity but it is also known to be quite militant. The religious issues alongside direct instructions or appeals from the pesantren leaders, in this case, the Kiai, are crucial. In many acts of rejection and closure of entertainment and tourism venues in Madura, this group is known as the field troops who play the role and function as an executor group.

${ }^{45}$ Lihat Kosim, 'Kyai Dan Blater; Elite Lokal Dalam Masyarakat Madura'; Abdur Rozaki, Menabur Kharisma Menuai Kuasa; Kiprah Kyai Dan Blater Sebagai Rezim Kembar Di Madura (Yogyakarta: Pustaka Marwa, 2004); Abd - Hannan, 'Agama, Kekerasan, dan Kontestasi Politik Elektoral: Penggunaan Simbol Keagamaan Kiai dan Kekuasaan Blater dalam Pertarungan Politik Lokal Madura', Jurnal Sosiologi A\& a 12, no. 2 (18 December 2018): 187, https://doi.org/10.14421/jsa.2018.122-02. 
Meanwhile, at the bureaucratic level, they control tourism development in Madura through personal communication to the regional leadership level, the Regent. The tradition of leadership in Madura, which incidentally is held by a figure with a Kiai background or descent, is why the communication pattern between Islamic organizations and the Regent in Madura tends to be easy to establish. ${ }^{46}$ However, even though some regional leaders in Madura have a Kiai background, it does not necessarily guarantee that the communication process between the two will be dynamic and fluid. On the other hand, it is often tricky and deadlocked in some situations, including in the case of tourism development in Madura. That is why, in addition to trying through the bureaucracy, they (conservative Islamic organizations) are also trying to go through political channels.

At the political level, the efforts of Islamic organizations in Madura in controlling tourism activities in Madura generally go through the party route, the legislative power in the regional parliament sector. Based on information obtained in the field, several Islamic CSOs in Madura have political affiliations to certain party groups. The aim is to build political power at the parliamentary level. However, not all political parties can affiliate with them. In this case, they are very selective and rigid. The political parties that are members of them are political groups with the same ideology as them, namely parties that ideologically have an Islamic platform, or at least exist in one struggle, supporting their Islamic da'wah program and agenda in Madura. On the other hand, this group is very anti-political parties that are not aligned, let alone known to be close to particular ideologies or

${ }^{46}$ Erie Haryanto, 'Neo Sufisme Dan Gerakan Sosial Agama-Politik Di Madura', Proceedings of Annual Conference for Muslim Scholars 3, no. 1 (26 November 2019): 894-904.

47 Imadul Haq Fadholi, Wawancara Bersama Sekretaris Umum Forum Kyai Muda Madura, 21 February 2017.

${ }^{48}$ Mulyadi, 'Resto Wiraraja Pamekasan Ditutup, PKS Mendukung Penuh', FaktualNews.co, 22 June 2020, ideologies that contradict them, whether communism, liberalism, and the like. Included in it is the PDIP Party. It is unlawful for them to have affiliation with him, apart from being considered by them to be close to the communists, also because their policies are often not in favor of Muslims. ${ }^{47}$ As far as field data is concerned, several political parties with affiliations are PPP, PKB, and PAN. For now, these conservative Islamic CSOs are closer to PKS. Apart from ideological factors, it is also because of the views of those who see PKS as having the same frame as their struggle, especially in carrying out the sharia-ization agenda in Madura. ${ }^{48}$

\section{RELIGIOUS CONSERVATISM BEHIND ISLAMIC ORGANIZATIONS' RESISTANCE BEHAVIOR; A THEORETICAL ANALYSIS}

In terminology, resistance has the meaning of challenge. In English, resist can be interpreted as to refuse, hold back, challenge, and fight. ${ }^{49}$ Thus, what is meant by resistance is all forms of actions, attitudes, and behaviors that contain rejection, resistance, and opposition from individuals or groups of people against something they disapprove of, whether this is in the form of policies, regulations, or regulations, development, and so on. At the practical level, resistant behavior is identical to specific social actions, ranging from intimidation, repression, persuasion to acts of anarchism that lead to clashes and social friction. ${ }^{50}$. It is included in the resistant category here, namely the attitudes and actions of refusing conservative Islamic organizations in Madura to the existence or development of several tourisms.

James C. Scoot (1936) divided the causes of resistance into two categories based on the

https:/ faktualnews.co/2020/06/22/resto-wirarajapamekasan-ditutup-pks-mendukung-penuh/220068/.

49 Abdul Jalil, 'Resistensi Tradisi Terhadap Modernitas', Umbara 2, no. 2 (21 January 2019): 115-23, https://doi.org/10.24198/umbara.v2i2.20451.

${ }^{50}$ Sarah Mailleux Sant'Ana, 'James C. Scott, Weapons of the Weak. Everyday Forms of Peasant Resistance', Variations, 1 June 2007, 23-54, https://doi.org/10.4000/variations.486. 
triggering factors, namely direct causes of resistance and indirect cause. ${ }^{51}$ The immediate causes of resistance are circumstances or situations that show the penetration of certain social groups or groups against groups and/or groups outside them. Generally, this penetration is played by social classes (superior/superordinate) such as owners of capital, government, and apparatus, where they carry out hegemony to community groups that have a hierarchy below them (inferior/subordinate). In many cases, the direct resistance factor here is oppression, threats, and pressure, even coercion by landlords, government, capital owners and other parties ${ }^{.52}$ While the indirect resistance factor is a latent situation or condition that allows friction or conflict to occur. Generally, this indirect factor is in the form of hidden interests such as political and ideological interests ${ }^{.53}$ Based on the writer's understanding of James C. Scoot's thought, it is fair to say that if the factors causing the resistance action by conservative Islamic organizations in Pamekasan are related to tourism development in Madura, it is included in the category of direct factors. It is clearly illustrated by the pattern of resistance involving two different social classes, between the religious groups as the lower group and the local government as the upper social class.

As for the shape, James C. Scott divides resistance into three (3), closed resistance, semiopen resistance, and finally open resistance. Closed resistance is a form of resistance that is symbolic and ideological. It occurs more often in hidden areas such as issues, fights, and slander. While semi-open resistance is more about rejection through speeches and conveying aspirations, it is included in this category, namely social protest through peaceful speeches and

51 Stefan Dorondel, James C. Scott, Against the Grain. A Deep History of the Earliest States, 2018, 21-36, https://doi.org/10.13140/RG.2.2.21285.76005.

52 Diana Kim, 'Against the Grain: A Deep History of the Earliest States - By James C. Scott', Governance 32 (1 April 2019): 390-92, https://doi.org/10.1111/gove.12398.

53 Marie Mullaney, 'Book Review: Domination and the Arts of Resistance: Hidden Transcripts. James C. Scott', demonstrations. While the last resistance is open resistance, this type of resistance refers to all forms of resistance and rejection that are carried out in systematic and structured ways based on clear principles and vision and mission. The most obvious characteristic of this resistance is in this movement pattern which is thick with violence and anarchism such as hitting, yelling, berating, insulting, and all forms of rejection that contain violence. $^{54}$ This open resistance category includes acts of destruction and arson such as those carried out by conservative Islamic mass organizations in Pamekasan when they rejected and opposed regional tourism development policies in Madura.

The concept of resistance by James C. Scoot above actually has quite a correlation with conservatism. At least, the correlation can be found in the building of the two definitions, which both mention anarchism and violent biased actions or behavior. For conservatism itself, as mentioned earlier, the meaning of conservatism and containing a reactionary essence is also identical with the old-fashioned definition of puritanism. Reactionary means synonymous with opposition, against progress or reform; is contrary to revolutionary action; is contrary to legitimate government policy. Because of this nature, some people refer to conservative groups as short axis groups, sensitive and easily angered. High religious sentiments have implications for self-religious attitudes and behaviors that tend to prioritize exclusivism, even violence. In relation to the phenomenon of resistance of Islamic organizations in Madura to local tourism development, reactionary attitudes can be traced to attitudes and behavior in responding to the presence of the tourism industry and entertainment venues in a number of areas in

Journal of Modern History - J MOD HIST 65 (1 September 1993), https://doi.org/10.1086/244678.

${ }^{54}$ Mailleux Sant'Ana, 'James C. Scott, Weapons of the Weak. Everyday Forms of Peasant Resistance'; William Roseberry, 'James C. Scott, Domination and the Arts of Resistance: Hidden Transcripts', International Labor and Working-Class History 42 (1 September 1992), https://doi.org/10.1017/S0147547900011443. 
Madura. For example, the action against the operation of Bukit Bintang Tourism in Pamekasan Regency which then led to chaos, destruction and burning of kiosks and stalls in locations. In addition, conservatism in a reactionary sense can also be found in their political attitudes, which more often position themselves as opposition parties, launch harsh criticisms and fight government policies through massive mass mobilization and mobilization, as happened in the case of the construction of the KCM Mall cinema building in Pamekasan. Based on field data searches, this reactionary attitude emerged as a consequence of their normative and textual way of religion. In addition, the view that tourism is synonymous with disobedience and violation of religious norms is also one of the reasons why this group often emphasizes reactionary attitudes, so that it often causes social chaos in the community.

Kolot has the meaning of antiquity, has a habit of self that always upholds customs, adheres to the system of values and norms produced from previous times and is passed down from generation to generation. In the context of religion, the old-fashioned terminology is aimed at their religious traditions which always use normative sources as the sole reference. The normative sources in question include scriptures and other orthodoxy sources that come from the time of earlier religious scholars. At the same time, they tend to keep their distance from outside reality, especially the products of thought born of modernism such as science, technology, and communication and information media. ${ }^{55}$ In the context of the resistance of Islamic organizations to the tourism industry and entertainment venues in Madura, their old-fashioned or traditional views

55 Zulfadli Zulfadli, 'From Formalization of Sharia to Islamic Conservatism: The Post Reform of Islamic Movement Phenomena In West Sumatera', Al-A Raf: Jurnal Pemikiran Islam Dan Filsafat 17, no. 1 (9 September 2020): 1 24, https://doi.org/10.22515/ajpif.v17i1.2289.

56 Muhammad Zuhdi, 'Challenging Moderate Muslims: Indonesia's Muslim Schools in the Midst of Religious Conservatism', Religions 9, no. 10 (11 October 2018): 310, https://doi.org/10.3390/rel9100310. are clearly reflected in their literal and textual paradigm of thinking and religion, placing religious sacred texts as the sole basis, both in understanding and in carrying out religious rituals. The assumption that the tourism and entertainment industries can threaten and shift religious values in Madura actually arises due to the inability to understand religion with the external reality in a balanced and dialogical manner.

Besides reactionary and traditionalism, another characteristic of conservatism is puritanism ${ }^{.56}$ In terms of terminology, puritanism is identical with a pious attitude of life that considers luxury and pleasure as a sin. In contemporary Islamic discourse, puritanism is an understanding that assumes that the real Islam is the Islam that existed at the time of the Prophet and his companions. At that time, Islam was not at all contaminated by doctrine and sociological elements outside it such as the luxury and glitter of the world, deviations, ideologies and all other forms of (religious) thought. ${ }^{57}$ Because of this view, the puritan group has the spirit to carry out the visions and missions of purification of Islam from all things that are considered not by teachings of Islam that existed at the time of the Prophet and his companions. In the context of the phenomenon of resistance by Islamic organizations to the tourism industry and entertainment venues in Madura, this puritan attitude can be identified in a number of their actions which often use religion as a narrative justification. For example, the case of the Bukit Bintang Tourism that led to the burning was motivated by their assumption that the existence of Bukit Bintang Tourism could be a source of

57 Martin van Bruinessen, 'Contemporary Developments in Indonesian Islam: Explaining the "Conservative Turn"”, ISEAS-Y usof Ishak Institute., 1 January 2013, 1-20; Bryan Turner, Post-Westphalian America? Religious Conservatism and American Exceptionalism, 2014; Rusydi M Yusuf, 'Puritanisme dan Perkembangan Pendidikan Amerika Masa Kolonial', Buletin Al-Turas 26, no. 1 (2020): 14. 
immorality and evil. In relation to this, the informant said:

"Before we take action, we have been monitoring it for a long time. We have spies, we ordered our people to spy on the place there, some disguised themselves as visitors, and at that time there were indeed some who were caught." ${ }^{18}$

Apart from these reasons, there is also an assumption that a tourism place (Bukit Bintang) is classified as unethical. In addition to the unethical reason for being close to the pesantren circle, it is also contrary to the spirit of regional development which has so far emphasized the religious dimension, as clearly reflected in the jargon of the greatness of development in Pamekasan, which is identical to the development agenda based on the Islamic community movement called Gerbang Salam (Gerakan Pembangunan Masyarakat Islami).

\section{CONCLUSION}

From all the explanations above, we can conclude three critical points in this study: First, the conservatism values of Islamic organizations in Madura were born and spread widely from local traditions and religions thick with traditionalism. In general, we can find the practice of religious conservatism in all mass organizations, especially Islamic organizations that are ideologically rightwing such as AUMA, FKM, and GUIP. As an association, conservative Islamic organizations in Madura have a significant position and influence. The magnitude of their influence can be seen from their dominance in controlling the course of development in Madura, including in regional tourism development. In this regard, it is not uncommon for this group to take action against any tourism development in Madura, contrary to the truth and religious values they believe in. In general, this resistance attitude takes the form of several actions, including appeals, refusals, forced

58 RKH. Ali, Interview Bersama Kyai Pesantren, Pandangan Kyai Pesantren terhadap Pembangunan Pariwisata di Madura. closures, to acts of anarchism in the form of burning, as happened in the case of burning the Bukit Bintang tourist spot in Pamekasan.

Second, to ensure the agenda is successful, they carry out their vision by utilizing social networks, either through religious, bureaucratic, and political channels. On the religious path, this group takes advantage of the existence of the pesantren community. While on the bureaucratic, they build communication with regional leaders, in this case, the Regent. As for the political path, they take this path through affiliation with political parties, one of which is with the PKS party. We can find the conservatism of Islamic organizations related to their resistance to the presence of the tourism industry and entertainment venues in Pamekasan in their religious thoughts and behavior, which highlight traditionalist, reactionary, and puritanical attitudes.

Third, despite the findings above, this research still leaves several weaknesses and limitations, one of which concerns the study locus, which has not fully touched the whole area in Madura. Based on the case, the locus of this study is more concerned with issues of tourism development in the Pamekasan Regency area. Therefore, it is crucial to carry out further studies or further research, especially targeting loci outside Pamekasan Regency. Considering the problem of resistance by Islamic organizations to tourism development in Madura is complex. It almost occurs in every area in the Madura Islands, in the west pole of Madura, such as Sampang and Bangkalan, and the east pole of Madura, including Pamekasan and Sumenep. 


\section{BIBLIOGRAPHY}

A la, Abd, Ahwan Mukarrom, and Mukhammad Zamzami. 'Islam Dan Agamaisasi Politik: Studi Analisis Terhadap Peran Dan Pergerakan Forum Kiai Muda (FKM) Pamekasan Madura'. Jurnal Review Politik 8, no. 1 (22 February 2019). http://jurnalfuf.uinsby.ac.id/index.php/JRP/ article/view/1089.

A la, Abd, Mukhammad Zamzami, Nur Hidayat Wakhid Udin, and Ahmad Fathan Aniq. 'Islamism in Madura: From Religious Symbolism to Authoritarianism'. Journal of Indonesian Islam 12, no. 2 (1 December 2018): 159.

https://doi.org/10.15642/JIIS.2018.12.2.159194.

Abdullah, KH.H. Interview Bersama Ulama/Kiai Pesantren, 3 June 2020.

Abdurrahman. Sejarah Madura Selayang Pandang. Sumenep: Matahari, 1988.

Agency, ANTARA News. 'Kiai Muda Datangi Bupati Pamekasan Tolak Konser Irwan'. ANTARA News Jawa Timur, 21 April 2016. https://jatim.antaranews.com/berita/176401 / kiai-muda-datangi-bupati-pamekasan-tolakkonser-irwan.

Aidulsyah, Fachri, and Yuji Mizuno. 'The Entanglement Between Anti-Liberalism And Conservatism: The INSISTS and MIUMI Effect within the "212 Movement" in Indonesia'. JOURNAL OF INDONESLAN ISLAM 14, no. 1 (1 June 2020): 1. https://doi.org/10.15642/JIIS.2020.14.1.125.

A'la, Abd, Ahwan Mukarrom, and Mukhammad Zamzami. 'Kontribusi Aliansi Ulama Madura (AUMA) dalam Merespons Isu Keislaman dan Keumatan di Pamekasan Madura'. Religió: Jurnal Studi Agama-agama 8, no. 2 (8 September 2018):

227-55. https://doi.org/10.15642/religio.v8i2.793.

. 'Kontribusi Aliansi Ulama Madura (AUMA) dalam Merespons Isu Keislaman dan Keumatan di Pamekasan Madura'. Religió: Jurnal Studi Agama-agama 8, no. 2 (8 September 2018):

$227-55$. https://doi.org/10.15642/religio.v8i2.793.
Amrullah, Afif. 'Islam Di Madura'. Islamuna: Jurnal Studi Islam 2, no. 1 (5 June 2015): 56. https://doi.org/10.19105/islamuna.v2i1.654.

Ariefana, Pebriansyah. 'Ribuan Anggota FPI Turun ke Jalan Demo Mal: Bioskop Sumber Kemaksiatan'. suara.com, 15 February 2020. https://jatim.suara.com/read/2020/02/15/0 60000/ribuan-anggota-fpi-turun-ke-jalandemo-mal-bioskop-sumber-kemaksiatan.

'Arti Kata Kolot - Kamus Besar Bahasa Indonesia (KBBI) Online'. Accessed 22 January 2021. https://kbbi.web.id/kolot.

'Arti Kata Reaksioner - Kamus Besar Bahasa Indonesia (KBBI) Online'. Accessed 22 January 2021. https://kbbi.web.id/reaksioner.

Asdhiana, Made. 'Ulama Madura Segel Hotel Berbintang'. https://ekonomi.kompas.com/, $27 \quad$ April 2011. https://ekonomi.kompas.com/read/2011/04 /27/19145853/ulama.madura.segel.hotel.ber bintang.

Asia, Dan. 'A Conservatism That Makes No Sense'. Academic Questions 33, no. 2 (1 October 2020): 1-5. https://doi.org/10.1007/s12129-02009920-8.

Atika. Respon Masyarakat terhadap Pembakaran Pariwisata Bukit Bintang di Pamekasan, 23 January 2021.

Azra, Azyumardi. 'Konservatisme Agama'. Republika Online, 1 August 2019. https://republika.co.id/berita/pvistt282/kon servatisme-agama-1.

BPS Pamekasan. 'Badan Pusat Statistik Kabupaten Pamekasan'.

https://pamekasankab.bps.go.id/. Accessed $29 \quad$ January 2021. https://pamekasankab.bps.go.id/.

Bruinessen, Martin van. 'Contemporary Developments in Indonesian Islam: Explaining the "Conservative Turn". ISEAS-Yusof Ishak Institute., 1 January 2013, 1-20.

Bruinessen, Martin van. "Tarekat and Tarekat Teachers in Madurese Society". In Across Madura Strait: The Dynamics of an Insular Society, Edited by Kees van Dijk, Hunb de Jonge, and Elly Tounven-Bounsma. Leiden: KITLV Press, 1995.

Burhani, Ahmad Najib. 'Lessons from Madura: NU, Conservatism and the 2019 Presidential Election', no. 2019 (2019): 9. 
Civettini, Nicole, and Jennifer Glass. 'The Impact of Religious Conservatism on Men's Work and Family Involvement'. Gender \& Society GENDER SOC 22, no. 3 (1 April 2008): 17293.

https://doi.org/10.1177/0891243207310714.

Coren, Daniel. 'Epistemic Conservatism and Bare Beliefs (Synthese)'. Synthese 198 (1 January 2021). https://doi.org/10.1007/s11229-01802059-8.

Departemen Pendidikan dan kebudayaan. Kamus Besar Bahasa Indonesia (Edisi Kedua). Jakarta: Balai Pustaka, 1999.

Dorondel, Stefan. James C. Scott, Against the Grain. A Deep History of the Earliest States, 2018. https://doi.org/10.13140/RG.2.2.21285.760 05.

Fadholi, Imadul Haq. Wawancara Bersama Sekretaris Umum Forum Kiai Muda Madura, 21 February 2017.

Gumilang, Prima. 'Sweeping Laskar FPI dan Perlawanan Balik Warga Pamekasan'. https://www.cnnindonesia.com/, 22 January 2018.

https://www.cnnindonesia.com/nasional/20 180122065509-20-270593/sweeping-laskarfpi-dan-perlawanan-balik-warga-pamekasan.

Hannan, Abd. 'Islam Moderat dan Tradisi Popular Pesantren: Strategi Penguatan Islam Moderat di Kalangan Masyarakat Madura melalui Nilai Tradisi Popular Islam Berbasis Pesantren'. Jurnal Sosiologi Dialektika 13, no. 2 (16 May 2020):

152.

https://doi.org/10.20473/jsd.v13i2.2018.152 -168 .

'Moderatisme dan Problem Konservatisme Beragama di Tengah Pandemi Global Covid19'. Jurnal KURIOSITAS; Media Komunikasi Sosial dan Keagamaan 13, no. 2 (Desember 2020): 31.

'Problem Tafsir Gerbang Salam'. Kabar Madura, $\quad 10 \quad$ March 2020. https://kabarmadura.id/problem-tafsirgerbang-salam/.

Hannan, Abd -. 'Agama, Kekerasan, dan Kontestasi Politik Elektoral: Penggunaan Simbol Keagamaan Kiai dan Kekuasaan Blater dalam Pertarungan Politik Lokal Madura'. Jurnal Sosiologi Agama 12, no. 2 (18 December 2018):
187. https://doi.org/10.14421/jsa.2018.12202.

Hannan, Abd, and Zainuddin Syarif. 'Agama Dan Politik: Konstelasi Pemikiran Antara Kelompok Kultural Dan Struktural Pada Kalangan Kiai Pesantren Di Madura'. Mawa'izh: Jurnal Dakwah Dan Pengembangan Sosial Kemanusiaan 11, no. 1 (4 June 2020): $47-$ 73.

https://doi.org/10.32923/maw.v11i1.1174.

Hariyanto, Erie. 'GERBANG SALAM: Telaah Atas Pelaksanaanya Di Kabupaten Pamekasan'. Karsa: The Journal of Social and Islamic Culture 15 (1 March 2012). https://doi.org/10.19105/karsa.v15i1.116.

Haryanto, Erie. Neo Sufisme Dan Gerakan Sosial Agama-Politik Di Madura'. Proceedings of Annual Conference for Muslim Scholars 3, no. 1 (26 November 2019): 894-904.

Hiar, Hairil. 'Top 3: Pulau Berkadar Oksigen Terbaik Dunia Ada di Madura'. liputan6.com, 19 July 2016.

https://www.liputan6.com/regional/ read/25 56406/top-3-pulau-berkadar-oksigen-terbaikdunia-ada-di-madura.

Indonesia, C. N. N. 'Diiringi Takbir, Massa Bakar Kedai Bukit Bintang di Pamekasan'. https://www.cnnindonesia.com, 10 May 2020.

https://www.cnnindonesia.com/nasional/20 201005132718-20-554475/diiringi-takbirmassa-bakar-kedai-bukit-bintang-dipamekasan.

Jalil, Abdul. 'Resistensi Tradisi Terhadap Modernitas'. Umbara 2, no. 2 (21 January 2019). https://doi.org/10.24198/umbara.v2i2.20451

JawaPos.com. 'Pengelolaan Wisata Belum Maksimal', $23 \quad$ January 2018. https://radarmadura.jawapos.com/read/2018 /01/23/42575/pengelolaan-wisata-belummaksimal.

Karrar, KH. Umar Hamdan. Wawancara Bersama Ketua Forum Kiai Muda Madura, 30 July 2018.

Kim, Diana. 'Against the Grain: A Deep History of the Earliest States - By James C. Scott'. Governance 32 (1 April 2019): 390-92. https://doi.org/10.1111/gove.12398. 
Kosim, Mohammad. 'Kiai Dan Blater; Elite Lokal Dalam Masyarakat Madura'. Karsa: The Journal of Social and Islamic Culture 12 (28 April 2012). https://doi.org/10.19105/karsa.v12i2.139.

kumparan. 'Pulau di Sumenep Ini Punya Oksigen Terbaik ke-2 di Dunia'. kumparan. Accessed 30

January

2021.

https:/ / kumparan.com/kumparantravel/pula u-di-sumenep-ini-punya-oksigen-terbaik-ke-2di-dunia-1rYusRzdcJK.

Ma'arif, Samsul. The History of Madura; Sejarah Panjang Madura Dari Kerajaan, Kolonialisme, Sampai Kemerdekaan. Yogyakarta: Araska, 2015.

Madjid, Nurcholis. Bilik- Bilik Pesantren Sebuab Potret Perjalanan. Jakarta: Paramadina, 1992.

maduranewsmedia. 'AUMA Dan FKM Tolak Konser Irwan di Pamekasan'. MADURA Newsmedia (blog), $20 \quad$ April 2016. https://maduranewsmedia.com/terkini/auma -dan-fkm-tolak-konser-irwan-di-pamekasan/.

Mailleux Sant'Ana, Sarah. 'James C. Scott, Weapons of the Weak. Everyday Forms of Peasant Resistance'. Variations, 1 June 2007, 153-56. https://doi.org/10.4000/variations.486.

MATAMADURANEWS.COM. 'Hadiri Tabligh Akbar Di Pamekasan, Habib Rizieq Serukan Partai Pendukung Penista Agama Tak Boleh Didukung Ulama - Mata Madura'. https://matamaduranews.com/, 13 April 2017. https://matamaduranews.com/hadiritabligh-akbar-di-pamekasan-habib-rizieqserukan-partai-pendukung-penista-agama-takboleh-didukung-ulama/.

Mudzakkir, Amin. 'Konservatisme Islam dan Intoleransi Keagamaan di Tasikmalaya'. Harmoni 16, no. 1 (30 June 2017): 57-74. https://doi.org/10.32488/harmoni.v16i1.56.

Mullaney, Marie. 'Book Review:Domination and the Arts of Resistance: Hidden Transcripts. James C. Scott'. Journal of Modern History - J MOD HIST $65 \quad$ (1 September 1993). https://doi.org/10.1086/244678.

Mulyadi. 'Resto Wiraraja Pamekasan Ditutup, PKS Mendukung Penuh'. FaktualNews.co, 22 June 2020.

https:/ / faktualnews.co/2020/06/22/restowiraraja-pamekasan-ditutup-pks-mendukungpenuh/220068/.
MURATORIO, BLANCA. 'Weapons of the Weak: Everyday Forms of Peasant Resistance. JAMES C. SCOT'T'. American Ethnologist 14 (28 October 2009): 585-86. https://doi.org/10.1525/ae.1987.14.3.02a003 30 .

Nurhayati, Alfisah. 'Revisiting Pariwisata Madura; Studi Kebijakan Pembangunan Kepariwistaan Kabupaten Sampang'. KARSA 18, no. 2 (2010): 11.

Nurif, Muchammad, and Endang Sulastri. 'Analisis Perubahan Eksternal dalam Pengembangan Kawasan Wisata Bahari Kepulauan Sapeken Madura dengan Menggunakan Pendekatan Pemasaran Wilayah'. Jurnal Sosial Humaniora 10, no. 2 (n.d.): 13.

Pribadi, Yanwar. 'Religious Networks in Madura: Pesantren, Nahdlatul Ulama, and Kiai as the Core of Santri Culture'. Al-Jami'ah: Journal of Islamic Studies 51, no. 1 (15 June 2013): 1. https://doi.org/10.14421/ajis.2013.511.1-32. . 'The Suramadu Bridge Affair: Un-Bridging the State and the Kiai in New Order Madura'. Studia Islamika 22, no. 2 (2 September 2015). https://doi.org/10.15408/sdi.v22i2.1919.

Rahmawati, Fithriyah. 'Strategi Pembangunan Pariwisata Daerah Berkelanjutan Melalui Konsep Ekowisata Berbasis Kearifan Lokal' 2, no. 1 (June 2020): 24.

Redpel. 'Penutupan Cafe Wiraraja Terkesan Aksi Simbolis Satpol PP'. JATIM POS online, 23 June

202AD. https://www.jatimpos.co/jatim/pantura/242 3-penutupan-cafe-wiraraja-terkesan-aksisimbolis-satpol-pp.

RKH. Ali. Interview Bersama Kiai Pesantren, Pandangan Kiai Pesantren terhadap Pembangunan Pariwisata di Madura, 24 January 2021.

Roseberry, William. 'James C. Scott, Domination and the Arts of Resistance: Hidden Transcripts'. International Labor and Working-Class History 42 (1 September 1992). https://doi.org/10.1017/S014754790001144 3.

Rozaki, Abdur. Menabur Kharisma Menuai Kuasa; Kiprah Kiai Dan Blater Sebagai Rezim Kembar Di Madura. Yogyakarta: Pustaka Marwa, 2004. 
Saputro, Muhammad Endy. 'Muslim Localizing Democracy:A Non-Pesantren Village in Madura as a Preliminary Study'. Indonesian Journal of Islam and Muslim Societies 1, no. 2 (1 December 2011): 297. https://doi.org/10.18326/ijims.v1i2.297-316.

Solopos.com. 'Sumber Maksiat! Massa FPI Demo Tutup Bioskop di Pamekasan', 16 February $2020 . \quad$ https://m.solopos.com/sumbermaksiat-massa-fpi-demo-tutup-bioskop-dipamekasan-1047150.

Syarif, Zainuddin, and Abd Hannan. 'Kearifan Lokal Pesantren Sebagai Bangunan Ideal Moderasi Islam Masyarakat Madura'. ISLAMICA: Jurnal Studi Keislaman 14, no. 2 (1 March 2020): 220 40.

https://doi.org/10.15642/islamica.2020.14.2. 220-240.

Tasnur, Irvan. 'Akar dan Perkembangan Konservatisme Islam dalam Perpolitikan Indonesia'. Jurnal review Politik 09, no. 1 (2019): 22.

Tempo.co. 'Disegel Kiai, Hotel Terbesar Di Madura Dijual $\quad \therefore$ Nasional Tempo.co, Mei 2011. https://nasional.tempo.co/read/333261/dise gel-kiai-hotel-terbesar-di-madura-dijual.

Turner, Bryan. Post-Westphalian America? Religious Conservatism and American Exceptionalism, 2014.

Wahid, Din. 'Kembalinya Konservatisme Islam Indonesia'. Studia Islamika 21, no. 2 (12 November 2014). https://doi.org/10.15408/sdi.v21i2.1043.

Yaqin, Nasrullah Ainul. 'Adakah Pengaruh Penerapan Syariat Islam di Pamekasan Terhadap Lingkungan?: Studi Kasus Kerusakan Laut di Desa Batukerbuy'. Al-Irfan: Journal of Arabic Literature and Islamic Studies 1, no. 1 (8 October 2018): 141-81. https://doi.org/10.36835/alirfan.v1i1.3225.

Yusuf, Rusydi M. 'Puritanisme dan Perkembangan Pendidikan Amerika Masa Kolonial'. Buletin Al-Turas 26, no. 1 (2020): 14.

Zuhdi, Muhammad. 'Challenging Moderate Muslims: Indonesia's Muslim Schools in the Midst of Religious Conservatism'. Religions 9, no. 10 (11 October 2018): 310. https://doi.org/10.3390/rel9100310.

Zulfadli, Zulfadli. 'From Formalization of Sharia to Islamic Conservatism: The Post Reform of
Islamic Movement Phenomena In West Sumatera'. Al-A Raf: Jurnal Pemikiran Islam Dan Filsafat 17, no. 1 (9 September 2020): 1-24. https://doi.org/10.22515/ajpif.v17i1.2289. 